\title{
Investigation and protection of drinking water source environment status of Yulin in Guangxi City
}

\author{
Xiuu Bu, Jinsong Guo, Guangqing Zeng, Yazi He, Jie Liao \\ Guangxi Zhuang Autonomous Region Environmental Protection Science Research Institute, \\ Nanning 530022, China
}

Keywords: drinking water; water source; Protection Countermeasures.

\begin{abstract}
In recent years, environmental protection and management of drinking water sources have aroused widespread concern in the community. In this paper, firstly introduce the basic information of the water source; secondly analysis the reserve source of pollution status of drinking water and evaluation; in the end, put forward Protection countermeasures and suggestions of the drinking water source.
\end{abstract}

\section{Introduction}

The Party Central Committee, the State Council attaches great importance to the safety of drinking water, which called "to strengthen the protection of drinking water sources is the primary task so that the people can drink safe water" environmental protection work as a priority among priorities. Eighteen big reports pointed out, "to strengthen the social construction must ensure and improve people's livelihood as the key", "to strengthen the protection of water resources and water quantity management".

The basic information of the water source. According to the survey, the county level centralized drinking water source is 19 or above in Yulin city in 2011 December approved by the Autonomous Region People's government. The River drinking water sources is in 6, accounting for 31.6\%, water source of drinking water reservoir is in 13 , accounting for $68.4 \%$; the source of drinking water is 12 , accounting for $63.1 \%$, alternate source of drinking water is 6 , accounting for $31.6 \%$; the planning and construction of drinking water source is 1 , accounted for $5.3 \%$.

\section{The environmental quality of drinking water source}

The water quality monitoring situation. About the 19 at or above centralized drinking water source in Yulin did not carry out the water quality monitoring of water is 10 , accounting for $52.63 \%$, and the water quality status and changing situation has been unclear. Only 9 sources is to carry out monitoring, accounting for $47 \%$ of the total number of water sources, and only 3 water source is for 28 (River) or 30 (reservoir) index monitoring, reached the requirement of monitoring frequency; the other 6 sources is only monitoring indicators, monitoring frequency does not meet the relevant requirements.

Water quality status of water sources. In 2012, 9 water source of Yulin city is to carry out monitoring, among which, only 1 water quality reached standard and the rest are not up to the standard, exceed the standard factor is mainly dissolved oxygen, five days biochemical oxygen demand, ammonia nitrogen, total phosphorus and fecal coli form bacteria.

\section{The reserve source of pollution status of drinking water and evaluation}

Evaluation methods of pollution sources -- equal standard pollution load method. Evaluation of various pollutants is on multiple sources of pollution and emissions by equal standard pollution load method to determine the main pollution sources and pollutants. As a unified comparison scale, the equal standard pollution load, the environmental impact of various pollution sources and pollutants are comparing the size. 
Some pollutants equal standard pollution load $=$ pollutant emissions $(\mathrm{t} / \mathrm{a}) /$ limit environmental quality standards (mg/L).

$\mathrm{Pi}=\mathrm{qi} / \mathrm{Coi}$

The total $\mathrm{P}=\sum \mathrm{Pi}$

$\mathrm{RI}=\mathrm{Pi} / \mathrm{P} * 100 \%$

Formula: Pi - I pollutants equal standard pollution load;

$\mathrm{Qi}$ - the amount of pollutants discharged in. (t/a);

Coi - I pollution evaluation standard (mg/L);

The total P, total pollutant equal standard pollution load;

RI single pollution load ratio of pollution. Some sources of pollution load are the source of pollution emissions of various pollutants and the pollution load of the total.A system of equal standard pollution load is the sum of the pollution source and pollution load.

\section{The results of source of pollution evaluation}

The protection of drinking water source in the area is mainly the life source of pollution, industrial pollution, agricultural pollution source, pollution source. Total pollutant emissions are of 9282.04 tons, the COD emissions are of 6355.54 tons, ammonia nitrogen emissions reach to 1351.22 tons, the total emissions are of 294.19 tons, total nitrogen emissions reach to 1281.09 tons.

From the analysis of pollution source type, the life source of pollution, industrial pollution, agricultural pollution source, pollution source pollution load ratio are $10.39 \%, 24.49 \%, 13.14 \%$ and $51.98 \%$ respectively, and the aquaculture pollution is the main source of drinking water pollution.

Tab1. The load statistics of centralized drinking water source protection areas pollution in Yulin City.

\begin{tabular}{|c|c|c|c|c|c|c|c|}
\hline $\begin{array}{l}\text { Pollution } \\
\text { source type }\end{array}$ & $\begin{array}{l}\text { COD } \\
\text { emissions } \\
\text { (tons) }\end{array}$ & $\begin{array}{l}\text { Ammonia } \\
\text { emissions } \\
\text { (tons) }\end{array}$ & $\begin{array}{c}\text { Total } \\
\text { phosphorus } \\
\text { emissions } \\
\text { (tons) }\end{array}$ & $\begin{array}{l}\text { Total } \\
\text { nitrogen } \\
\text { emissions } \\
\text { (tons) }\end{array}$ & $\begin{array}{l}\text { Equal } \\
\text { standard } \\
\text { pollution } \\
\text { load }\end{array}$ & $\begin{array}{c}\text { Equal } \\
\text { standard } \\
\text { pollution } \\
\text { load ratio } \\
(\%) \\
\end{array}$ & \\
\hline $\begin{array}{l}\text { Aquaculture } \\
\text { pollution source } \\
\text { Industrial }\end{array}$ & 916.85 & 156.34 & 222.91 & 920.23 & 556.78 & 51.98 & 1 \\
\hline $\begin{array}{l}\text { pollution } \\
\text { sources } \\
\text { Agricultural }\end{array}$ & 2287.21 & 1059.51 & 1.44 & 26.98 & 262.32 & 24.49 & 2 \\
\hline $\begin{array}{l}\text { pollution } \\
\text { sources }\end{array}$ & 1399.19 & 41.97 & 45.82 & 191.5 & 140.77 & 13.14 & 3 \\
\hline $\begin{array}{c}\text { The life source } \\
\text { of pollution } \\
\text { Total }\end{array}$ & $\begin{array}{l}1752.29 \\
6355.54\end{array}$ & $\begin{array}{c}93.40 \\
1351.22\end{array}$ & $\begin{array}{c}24.02 \\
294.19\end{array}$ & $\begin{array}{c}142.38 \\
1281.09\end{array}$ & $\begin{array}{c}111.25 \\
1071.12\end{array}$ & 10.39 & 4 \\
\hline $\begin{array}{l}\text { Equal standard } \\
\text { pollution load }\end{array}$ & 127.11 & 270.24 & 588.38 & 85.41 & 1071.12 & I & / \\
\hline $\begin{array}{l}\text { Equal standard } \\
\text { pollution load } \\
\text { ratio }(\%)\end{array}$ & 11.87 & 25.23 & 54.93 & 7.97 & / & I & I \\
\hline Sort & 3 & 2 & 1 & 4 & l & l & 1 \\
\hline
\end{tabular}

Monitoring ability. At present, only the Yulin city and Beiliu City, environmental monitoring station has been the measurement certification, have the ability of water quality monitoring, and environmental monitoring station in Rongxian County, Lu Chuan County, Bobai County and the county are without laboratory metrology accreditation, and only with a part of the water quality monitoring equipment.

Water signs and protective facilities. Yulin City, only a part of water carried signs set to work, and sign up is not perfect enough, mark set completion rate was only $8.31 \%$, but all the water did not reach the requirement set by the number of signs. Only 5 sources provided some signs, without a sign of water accounted for $74 \%$ of the total. There is still no protective facilities were not provided $84 \%$ of the water around the water intake. 


\section{Protection countermeasures and suggestions of the drinking water source}

The problems of coordinate urban planning and construction and protection of drinking water. In the stage of development planning of city, county, we should fully consider the coordination problem of city construction and protection of drinking water. One is the water resources utilization and planning must give priority to the protection of drinking water sources in the first place, and everything is not consistent with drinking water safety of construction projects and planning must be the full argument, proposed alternatives to construction.

To strengthen the protection of sources of pollution zone control. The protection and improvement are of key water quality of drinking water source, which is the control of point source and area source pollution control. On the water, the people's governments at all levels of environmental protection departments are nine-depth investigation and its upstream environmental risk sources, prevention and control of pollution source inventory lists, and the deadline governance. The sewage is in accordance with the demolition of water protection areas and export.

Lifting water source monitoring ability. Construction of the city is at the county two levels of water quality monitoring network system through the improvement of equipment, which will strengthen the training of technical personnel and other measures. At the same time, we should strengthen the Yulin city environmental monitoring station monitoring ability construction, which will promote Yulin city station specific toxic organic pollutants monitoring capacity; Rongxian County, Bobai, the county and Lu Chuan County to speed up the development of Metrology Accreditation monitoring laboratory.

\section{Conclusions}

The safety of drinking water is directly related to people's health and life safety, thus, strengthen the protection of drinking water sources is an important task of the people's livelihood. Therefore, grasp the water environment, pollution status and management situation in order to promote water pollution remediation work, and effectively improve the level of security of drinking water.

\section{References}

[1] WORLD WATER COUNCIL. World wat er vision 2025 [M] . Earthscan Pu blications Ltd, 2000.

[2] Qian Ying, Zhang Guangdou. Chinese strategic research for sustainable development of water resources (consolidated report and Thematic report) [M] Beijing: China Water Power Press, 2001.

[3] Chinese Academy of Engineering? Sustainable Water Resources Development Strategy of China in the 21st century? Project Groups. Chinese Sustainable Integrated Water Resources Strategy Research Report development[J]. Chinese engineering Science, 2000, 2 (8): 1 17.

[4] Chen Kai. Sustainable utilization of water resources of China [J]. Chinese water conservancy, 2000 (8): $38 \sim 40$. 